\title{
Multidisciplinarity in Education for Digital Librarianship
}

\author{
Terry L. Weech \\ Graduate School of Library and Information Science, \\ University of Illinois at Urbana-Champaign, IL, USA
}

\author{
weech@uiuc.edu
}

\begin{abstract}
As information resources of all types and disciplines are being stored and retrieved in digital form, libraries are responding to the demands for more effective retrieval of such documents and to provide even more digital access to scholarly and recreational library materials. This has led schools of library and information science to develop special programs, degrees, and certificates in digital librarianship. These programs vary from one school to another, but they all demonstrate the multidisciplinarity of education for librarians who will work specifically with digital librarianship. Library and Information Science education has always had a multidiscipline orientation, with traditional faculty consisting of those with degrees in the fields of sociology, communications, history, public administration, education, engineering, and computer science, as well as advanced degrees in library and information science. But with the advent of special programs in digital librarianship, the curriculum has begun to switch to a multidiscipline curriculum content which may be evolving into a sub-specialization in the field. These trends are examined in this paper and recommendations are made regarding future research needed to determine the advisability and sustainability of this trend.
\end{abstract}

Keywords: Digital libraries, Library education, Library science curriculum, Libraries and technology.

\section{Introduction}

Library and Information Science (LIS) education has, since its founding in the late $19^{\text {th }}$ century, incorporated expertise from other disciplines. Early professional degrees in library science which were listed as "fifth-year" bachelor's degrees to be undertaken after earning a traditional four- year bachelor's degree in the liberal arts and sciences. The fifth-year professional degree assumed that students would bring a background in a discipline other than library and information science to draw on as they learned the theories and professional skills of librarianship. This acknowledgement of need for knowledge from many disciplines was central to the practice of

Material published as part of this publication, either on-line or in print, is copyrighted by the Informing Science Institute. Permission to make digital or paper copy of part or all of these works for personal or classroom use is granted without fee provided that the copies are not made or distributed for profit or commercial advantage AND that copies 1) bear this notice in full and 2) give the full citation on the first page. It is permissible to abstract these works so long as credit is given. To copy in all other cases or to republish or to post on a server or to redistribute to lists requires specific permission and payment of a fee. Contact Publisher@InformingScience.org to request redistribution permission. the profession of librarianship. It was not until the establishment of the Graduate Library School at the University of Chicago in 1928 that doctorates in LIS were offered. This course of study was created in large part to provide faculty for the growing number of LIS schools established in research level institutions of higher education. Of course, the original faculty of the 
University of Chicago Graduate Library School of necessity had their doctorates in disciplines other than library science, but once doctorates in library science were awarded at the University of Chicago, it became possible for library science programs to hire faculty with doctorates in the discipline of LIS. By 1948 the University of Michigan and the University of Illinois were also offering doctorates in LIS, and by the 1960s, it was common for library schools to turn to PhDs in LIS when hiring new faculty and new deans (Stieg, 1992). Thus LIS education had its origins in a multidisciplinary context and only some 40 years after the establishment of the first schools of library science was the research based doctorate in the discipline established.

\section{What is Multidisciplinarity?}

One of the most comprehensive reviews of multidisciplinarity and interdisciplinarity is Julie Klein's 1990 book Interdisciplinarity: History, Theory, and Practice. Klein reviews the many definitions of the terms interdisciplinary and multidisciplinary. She observes that most interdisciplinary activities are not "interdisciplinary" but "multidisciplinary." Her definition of "multidisciplinarity" is that it is the juxtaposition of disciplines, essentially additive, not integrative. She sees "interdisciplinarity,' on the other hand, as the integration of material from various disciplines into a new coherent entity (Smith, 1994).

There is comparatively little literature on multidisciplinarity in library and information science education. Other than an unpublished research report from Linda C. Smith, Associate Dean at the Graduate School of Library and Information Science, University of Illinois, on interdisciplinarity in library and information science education and research, there has been no reported research within the field. As Klein notes in her discussion of the "multidiscipli-

nary/interdisciplinary" distinction, most people who refer to interdisciplinary activities are really speaking of multidisciplinary activities. In our judgement, the indicators used by Linda Smith in her study are sufficiently relevant to the concept of multidisciplinarity (other disciplines being additive, not integrative), that we consider her results on interdisciplinarity to be relevant to this study of multidisciplinarity in LIS education programs.

Smith surveyed faculty and administrators of all 57 American Library Association accredited LIS programs in the fall of 1993 . Faculty from 56 schools responded with an overall response rate of $44 \%$. $(\mathrm{N}=626)$ Some of the indicators of interdisciplinarity used by Smith were:

- Membership in Professional Associations outside LIS, Review-Editorial Activities, publication in journals, conferences outside LIS

- Teaching-related interdisciplinary activities (readings, cross-listing courses, courses taught in other departments, etc.)

- Graduate degrees held by faculty outside LIS

Smith found that most faculty were members of LIS associations, although some were members of non-LIS associations. Approximately $25 \%$ of the faculty published outside LIS literature. About 33\% attended conferences outside LIS discipline areas and 20\% reported involvement in collaborative research. Use of readings from other fields on course reading lists was the most common teaching-related interdisciplinary activity. About $46 \%$ of faculty responding had at least one graduate degree outside LIS (Smith, 1993). While Smith's findings cannot be used to generalize to all library school faculty in 1993 because of the $44 \%$ response rate, the findings do confirm that a large number of LIS faculty in 1993 were already involved in interdisciplinary/multidisciplinary activities and behavior. In so far as part of the purpose of Smith's research was to provide a base line for future research, she was successful. Although no one has followed-up up on her research, we at least have a view of the interdisciplinary/multidisciplinary activities of nearly half of LIS faculty in 1993. 
As already noted, there are many variations of definitions that apply to the terms "interdisciplinary" and "multidisciplinary" in the literature. For purposes of this exploratory study, we will adopt the definition of "multidisciplinarity" as the concept of two or more disciplines sharing research and subject content but not incorporating in any one of the disciplines the methodological or conceptual assumptions of the other disciplines. Multidisciplinarity is a recognition of disciplines working together without integrating their professional or scholarly assumptions or epistemologies. In contrast, "interdisciplinarity" will be used to refer to two or more disciplines that do develop a shared research or subject content interest and integrate to some degree the methodological and conceptual view of the other disciplines in their shared efforts.

\section{What is a Digital Library?}

There is little consensus in the literature on what digital libraries are. The definitions range from "Digital libraries basically store materials in electronic format and manipulate large collections of those materials effectively" (DLI UIUC Glossary, 1998) to "A digital library comprises digital collections, services and infrastructure to support lifelong learning, research, scholarly communication and preservation" ("Digital library" Wikipedia, 2005).

Some definitions limit the content of digital libraries to traditional materials, such as the InterAcademy Council definition: "Digital libraries: collections of information - originally in the form of printed books, journals, and monographs; databases; photographs, motion pictures, and videos; sound recordings; and digital format - made accessible to everyone, everywhere in electronic format through organized sites on the World Wide Web" (InterAcademy Council, 2004). Some use the terms "Virtual Library" or "Electronic Library" to refer to what others call a digital library. In order to discuss educating people to work in digital libraries, we must adopt a definition so course work and skill requirements can be identified.

For purposes of this paper, a definition based on the Digital Libraries Federation working definition is adopted. That definition is: "Digital libraries are organizations that provide the resources, including the specialized staff, to select, structure, offer intellectual access to, interpret, distribute, preserve the integrity of, and ensure the persistence over time of collections of digital works so that they are readily and economically available for use by a defined community or set of communities" (Waters, 1998). This definition includes the functions found in most traditional libraries and seems most compatible with the tradition of education for library services found in most schools of library and information studies today. The major difference, of course, is the term "digital works" which takes the library beyond the traditional formats found in most libraries.

\section{Perceptions of Digital Librarianship in Literature}

Saracevic and Dalbello noted in 2001 that Library and Information Studies (LIS) education has not been a leader in the development of digital libraries, but as in so many other instances, a follower. They suggest that digital library research has been primarily done by computer scientists while the library and information studies community has focused on the applications and practice, not the research. They use the astronomical metaphor of the digital library research community and the digital library practice community being in the same planetary system, but one is on Mars and the other on Venus (Saracevic \& Dalbello, 2001, p. 212). The suggestion that librarians are focusing on practical applications (the Venus connection) while computer scientists are doing most of the ground breaking research that supports the practical applications (the Mars connection) seems to be borne out by an informal review of those in libraries and those teaching and doing research in schools of library and information studies. If Mars is associated with the male gender and Venus with female, most LIS faculty doing digital library research seem to be 
male and most librarians are female. Whether this gender pattern holds true when specific responsibilities for digital librarianship are examined remains to be determined. But there is more to the Mars and Venus distinction, of course than just gender. There may be other aspects, such as service orientation and holistic, community orientation that also contributes to the divisions implied by this planetary metaphor.

\section{Curricular Trends in Education for Digital Librarianship}

The term "digital library" developed from the applications of using the digital computer to store information. By the 1980s, computer science was taking the initiative in developing digital libraries. In the early 1990s libraries and library education became involved as funding for digital library projects became available. National funding sources had much to do with the focus on digital libraries in the U.S. and in the U.K. The first U.S. Federal Government funding began in 1994 with the federated Digital Library Initiative (DLI-1). Since 1994, additional funding has become available from numerous sources, including the National Science Foundation and the Institute for Museum and Library Services (Mischo, 2004). In the U.K, the "eLib" program was started in 1994 with funding for 70 digital library projects. Most of the eLib and U.S. Digital Libraries Initiative were focused on academic libraries and in the case of eLib, funds were allocated in smaller amounts to many library projects, while the U.S. Digital Library Initiative focused on a few large projects (Pinfield, 2004).

Spink and Cool conducted one of the first surveys of LIS course offerings in 1998 using two methods. They analyzed the websites of LIS schools to determine if courses were listed that dealt with digital libraries. They also placed an invitation on an LIS listserv on the web for people to respond with an indication as to whether they offered courses on digital libraries. Twenty institutions responded to the listserv that they had courses on digital libraries. Twelve of the respondents were from U.S. institutions, and of these, 10 were American Library Association (ALA) accredited programs. Of the eight from outside the U.S. one was from Europe (U.K.) and the rest were from areas outside Europe. The analysis of the websites confirmed the findings reported to the listserv. Most of the courses identified were technical in orientation and focused on construction of digital collections (Spink \& Cool, 1999).

A second survey on education for digital librarianship was done in 2001 by Savacevic and Dalbello. They used similar methods to Spink and Cool, but found a significant increase in the number of digital library courses offered at ALA accredited programs. Forty-seven (nearly $90 \%$ ) of the ALA accredited programs in 2001 had courses that dealt with digital libraries, but only 15 of these were specifically dedicated to digital libraries. The other courses identified by Saracevic and Dalbello were courses that included digital libraries as a unit in the course, but were not exclusively digital library courses. Saracevic and Dalbello took their analysis further and looked at the course content of the 47 courses that concerned digital libraries. They identified the following elements as part of the course content.

- knowledge management

- standards

- document structure and electronic text

- preservation

- community building and social context

The third survey of courses for education of digital librarians was done in 2003 by Yan Quan Liu. She also used the website analysis method and she examined library and information study programs around the world. She found 36 websites with digital library courses. This compares with 20 such websites found in 1999. Twenty of the 36 schools identified as having digital li- 
brary courses were ALA accredited programs, twice the number found in the 1999 survey. The remainder of the programs were computer science or LIS programs in Europe, South America or Asia. Among those programs that were in LIS, the course content tended to be technical in programs outside North America, while in North America content focused more on organizing, preserving, managing and providing access to collections (Liu, 2003).

A review of the results of these three surveys of LIS education for digital libraries suggests a grouping of elements. The three most common elements are Computer Science, Library and Information Studies, and Communication. There are a scattering of other elements, such as sociology, information technology, medical informatics, and so on. But for the most part, Computer Science and Library and Information Studies seem to have the strongest hold on what is taught for educating digital librarians.

\section{Skills needed for Digital Librarianship}

Spink and Cool, in their 1999 article, proposed a model curriculum for digital librarianship. They developed their content as a blend of LIS and Computer Science curricula to achieve a general digital libraries program of study. The following are their broad curricular headings and the content that might be offered under each heading:

Theoretical and Historical Foundations

History of libraries; Human information behavior; Information retrieval theory; Development of digital collections and digital libraries

Technical Infrastructure of the Digital Library

Information retrieval engines; Database construction of digital libraries; Distributed collections; Multimedia formats and applications; Interoperability; Network technology; Web applications in digital libraries; Interface design; Communication protocols; Query languages

Knowledge Organization in Digital Libraries

Metadata; Indexing; Classification; Database integration; Document formats

Collection Development and Maintenance

Digital archives; Digital conversion technology; Digital preservation

Information Access and Utilization of Digital Libraries

Users and uses of digital libraries; Usability and evaluation research; Information behavior in digital libraries

Social, Economic and Policy Issues

Electronic publishing; Scholarly communication; Copyright issues and intellectual property rights in digital libraries; Costs of building digital libraries; Funding for digital environments

Professional Issues

Roles and responsibilities of the digital librarian; Management of digital libraries; Bibliographic instruction

In 2002, Coleman raised some questions about the model curriculum content proposed by Spink and Cool. The questions included the following: 
- Would the recommended digital libraries curriculum increase Library and Information Studies (LIS) fragmentation?

- Would an approach that integrated Digital Librarianship (DL) into the standard LIS curriculum make a separate DL program unnecessary?

- Would a separate program for DL merely split LIS graduates into traditional and Information Technology-intensive roles?

- Should Library and Information Studies or Computer Science faculty teach in the DL program?

- What is the appropriate level (UG, Graduate, Post Master's ) to teach the DL program?

- What balance should there be between "Hands on" vs. Conceptual topics in DL programs? (Should emphasis be on tools and technologies or the environment and context?)

\section{Curricular Content and Research on Educational Programs in the US}

In an effort to answer some of these questions, this paper looks at the current state of education for digital librarianship in the U.S. by looking at four of the schools that have recently announced formal programs of study to educate students specifically in digital librarianship. These four schools are:

Indiana University - Master's Degree - DL Concentration http://lair.indiana.edu/research/dlib/

Rutgers University - Master's Degree - Digital Libraries Concentration online http://www.scils.rutgers.edu/programs/lis/OnlineMLIS.jsp

Syracuse University - Certificate of Advanced Study in Digital Libraries http://istweb.syr.edu/academics/graduate/mls/digitallibraries/index.asp

University of Illinois - Certificate of Advanced Study (6 ${ }^{\text {th }}$ year CAS degree) - Digital Libraries Concentration http://www.lis.uiuc.edu/programs/cas-dl.html

Note that two of the four programs are for the master's degree while the University of Illinois' program is for the $6^{\text {th }}$ year (post master's degree) certificate of advanced study and the Syracuse University program appears to be a post-bachelor's non-degree certificate. Also note that the Rutgers program is offered exclusively online. The other programs may have online delivery components, but they are also offered as residential programs on campus. The details of the courses required and/or recommended for each of these programs may be found in the Appendix of this paper.

A review of these four programs of study suggests a variety of skills are seen as appropriate for librarians working with digital libraries. Most have both computer science and LIS course content, although some specify that the courses are to be taken from the Computer Science schools, not LIS. Of the two master's degree curricula, Rutgers seems to have the most traditional LIS content within their electives, with courses such as Cataloging and Classification and Management of Libraries and IT for Libraries listed among the electives and two required noncredit LIS "core" professionalization courses. Indiana University, however, also requires a basic "core" of professional courses be taken in addition to the more technical electives listed. In both cases, 
the master's degree with a DL concentration is based on the foundation of library and information studies.

The CAS degrees, however, are not as clearly based on the LIS foundation and differ greatly from each other. The Syracuse University Degree is not a $6^{\text {th }}$ year degree, requiring only a bachelor's degree for admission. This CAS also indicates that "A library background is not a prerequisite for applying to this certificate program, although prior exposure to library work is desirable." (Syracuse University, 2005).

The University of Illinois CAS is a $6^{\text {th }}$ year degree beyond the master's degree and requires a master's degree in LIS or a closely related field. While "closely related field" is likely to be interpreted broadly to include computer science and other technical fields, the Illinois program does suggest a potentially closer tie to the LIS profession than the Syracuse University CAS.

How these courses of study finally work out will be something that time will determine. But clearly there is not a consensus on the skills required if the requirements for admission and graduation for the four programs being established in the U.S. are an indication.

\section{Questions on Multidiciplinarity and the Future of Education for Digital Librarianship}

As noted earlier in this paper, the research that has resulted in the technological applications that have made digital libraries possible has its origin in computer science and the technical side of information science. But the four prototype educational programs for digital librarians, as can be seen by the examples presented above, are based in schools of library and information studies. A review of the websites of highly ranked computer science programs did not identify any programs concentrating on training digital librarians. In 2003, Johns Hopkins University announced that it was establishing a concentration in digital libraries in a Master of Arts in Communication in Contemporary Society (Johns Hopkins University, 2003). By 2004 the degree in digital libraries had been abandoned and a Master's Degree in Communication with a concentration in digital technology was substituted (Johns Hopkins University, 2004). Johns Hopkins does not have and never has had a school of library and information studies. Is there a message in the decision by Johns Hopkins University to drop a concentration on Digital Libraries? At least this event should raise some questions for us, as librarians to consider.

One question might be whether educational programs with digital library concentrations are necessary? Could it be that the practice of digital librarianship has evolved beyond the need for specific programs in digital librarianship? If special concentrations in digital librarianship are not needed, what needs to be added or changed in our traditional education programs for librarianship to meet the skills required in digital librarianship?

The other question is the continuing role of multidiciplinary studies in education for digital librarianship. In the U.S. there has been a recent establishment of a group of schools concerned with Information Technology that have labeled themselves I-Schools. The web page for the group states that they are a group of "schools interested in the relationship between information, technology, and people." (I-Schools Project, 2006) This group, which includes some traditional schools of library and information science as well as schools that have a tradition in engineering and computer scicence, is reported to have as one of its primary criteria for membership the amount of grant awards received each year. These schools tend to be the most multidisciplinary of all the library and information science schools in the U.S. and Canada and education for digital librarianship is certainly a focus in their curriculia. Thus the question arises as to 
whether educating librarians for digital librarianship is moving LIS education to an even greater multidiscipliary currlculum that before. An reliated to this question is whether this is a good think in the long run? More reseearh is undoubtedly needed on the skills and competencies needed by librarians in the digital age. Specfically, how much of the traditional values of service found in librarianship should or can be retained as more faculty from other disciplines become the mentors for the librarians concentrating on digital librarianship? What sort of services will be needed by library users in digital libraries in the future? These are some of the questions that need to be explored as we enter an even more multidiciplinary environemnt in LIS education in the 21 st century.

\section{Conclusion}

Perhaps we are too critical of LIS education's lack of initiative in meeting the educational needs of digital librarians. It always takes time to adjust to new programs and specialities, especially in professional education. While the discussion as to whether there should be special programs for digital librarians or if all librarians should received the necessary education and skills to work in digital librarianship will continue for a few more years, it is likely the end result will be the integration of digital librarianship skills into the general course of study for professional librarians. This has been the pattern in the past as librarians considered new media, such as sound recordings, film, video, microformats, and computer applications. There is little reason to believe that Library and Infromation Science eduation will not rise to the new challenge and provide the necessary training and skills for digital librarianship in the 21 st Century.

\section{References}

Coleman, A. (2002). Interdisciplinarity: The road ahead for education in digital libraries. D-Lib Magazine, 8(7-8), June-July. Accessed July 14, 2005 from: http://www.dlib.org/dlib/july02/coleman/07coleman.html

Digital Libraries. (1998). DLI UIUC Glossary [online] Accessed July 14, 2005 from: http://dli.grainger.uiuc.edu/glossary.htm

Digital library. (2005). Wikipedia, the free encyclopedia. [online] Accessed July 14, 2005 from: http://en.wikipedia.org/wiki/Digital_libraries

InterAcademy Council. (2004). Inventing a better future (Annex D: Glossary, p. 258). [online] Accessed July 14, 2005 from: http://www.interacademycouncil.net/Object.File/Master/6/720/0.pdf

I-Schools Project. (2006). Homepage. Accessed November 24, 2006 from: http://www.ischools.org/oc/

Johns Hopkins University. (2003). Announces new concentration in digital libraries. [online] Accessed July 14, 2005 from: http://www.jhu.edu/advanced/communication/digital_libraries.html

Johns Hopkins University. (2004). New communication course offered this fall [online] Accessed July 14, 2005 from: http://www.jhu.edu/advanced/communication/

Liu, Y. (2004). Is the education on digital libraries adequate? New Library World, 105 (1196/1197), 6068.

Mischo, W. (2004). United States federal support for digital library research and its implications for digital library development. In Digital libraries: Policy, planning and practice (pp. 5-17). Hants, England: Ashgate Publishing.

Pinfield, S. (2004). eLib in retrospect: A national strategy for digital library development in the 1990s. In Digital libraries: Policy, planning and practice (pp. 19-34). Hants, England: Ashgate Publishing. 
Saracevic, T., \& Dalbello, M. (2001). A survey of digital library education. Proceedings of the ASIST Annual Meeting, 38, 209-223. Medford, NJ: Published for the American Society for Information Science and Technology by Information Today, Inc.

Smith, L. C. (1994). Interdisciplinarity in library and information science education and research (Unpublished Research Report, Champaign, IL, 1994)

Spink, A. \& Cool, C. (1999). Education for digital libraries. D-Lib Magazine, 5(5), 1-7. Accessed July 14, 2005 from: http://www.dlib.org/dlib/may99/05spink.html

Stieg, M. F. (1992). Change and challenge in library and information science education. Chicago: American Library Association.

Syracuse University. (2005). Academic programs: CAS in digital libraries: Admission. [online] Accessed July 14, 2005 from: http://istweb.syr.edu/academics/graduate/mls/digitallibraries/admission.asp

Waters, D. (1998). What are digital libraries? CLIR Issues, 4, July/August. [online] Accessed July 14, 2005 from: http:/www.clir.org/pubs/issues/issues04.html\#dlf

\section{Appendix - Education for Digital Library Programs Offered in the U.S. in 2005 University of Illinois - Certificate of Advanced Study (CAS) $6^{\text {th }}$ year degree - Digital Library Concentration.}

\section{$\underline{\text { Required Courses }}$}

1) Introduction to Digital Libraries

2) Information Modeling

3) Design of Digitally Mediated Information Services

4) Information Policy

\section{Elective Courses}

- Implementing Digital Libraries - Current Topics in Collection Development

- Architecture of Network Information Systems - Document Processing

- Implementation of Information Storage \& Retrieval Systems - Document Modeling

- Agents \& Multi-Agents for Dynamic Information Systems

- Electronic Publishing and Information Processing Standards

- Emerging Technologies and Community Information Systems

- Information Architecture - Interfaces to Information Systems

- Information Quality: Principles and Practices

- Data Administration Concepts and Database Management

\section{Indiana University - Master's Degree - DL Concentration}

\section{Concentration Course List}

- Digital Libraries

- Foundations of Information Architecture

- User-centered Database Design

- Metadata

- Computer Programming for Information Management

- Network Technologies and Administration (Computer Science)

- Information Storage and Retrieval Theory 
- User Interface Design

- Introduction to Human Computer Interaction

- Information Usage and the Cognitive Artifact

- Evaluation of Information Systems

- Information Policies, Economics, and Law

- Computerization in Society

- Seminar in Intellectual Freedom

- Internship in Library and Information Science

\section{Rutgers University - Master's Degree - Digital Libraries Concentration online}

Two Required noncredit classes,

1) Introduction to Library \& Information Professions and

2) Colloquium of Library \& Information Studies

Electives: At least twelve of the following courses:

Human Information Behavior

Interface Design

Organizing Information

Cataloging and Classification

Metadata for Information Professionals

Principles of Searching Reference Sources and Services

Information Retrieval

Automated \& Networked Systems

Digital Libraries

Information Visualization \& Presentation

Field Experience

Digital Library Technology

Multimedia Production

Management of Libraries and Information Centers

Information Technology for Libraries and Information Agencies

\section{Syracuse University - Certificate of Advanced Study in Digital Libraries}

\section{Three Required Courses}

1) Digital Libraries

2) Creating, Managing, and Preserving Digital Assets

3) Planning and Designing Digital Libraries Services

Electives:

Information Architecture for Internet Services

Distributed Computing for Information Professionals

Technologies in Web Content Management

Data Mining

Managing Information Systems Projects

Digital Retrieval Services

Theory of Classification and Subject Representation

Indexing and Abstracting Systems and Services

Behavior of Info. Users 
Human Interaction with Computers

Introduction to Telecommunications and Network Management

Basics of Information Retrieval Systems

Information Technology for Libraries and Information Centers

Knowledge Organization Structures

Designing Web-Based Database Systems

\section{Biography}

Terry L. Weech's professional positions have included Head of Government Documents, Illinois State Library; Research Associate, University of Illinois Library Research Center; and teaching positions at the University of Iowa, University of North Carolina, Chapel Hill, Emporia State University, and the University of Illinois. At the Graduate School of Library and Information Science, University of Illinois he has been Coordinator of Advanced Studies, Director of Development, and International Visitor's Liaison.

His research interests include collection development, library systems and networks, library administration, economics of information, measurement and evaluation of library services, and delivering library education via distance education on the Web. He has been active professionally at the state and national level in areas of intellectual freedom, access to government information, and library cooperation. He currently teaches courses dealing with reference, library cooperation, and the economics of information. He has worked with the Mortenson Center for International Librarianship at the University of Illinois in training of librarians and library educators from around the world and presented papers and conducted workshops in Argentina, Bulgaria, Croatia, Czech Republic, Estonia, France, Germany, Hungary, Ireland, Italy, Latvia, Lithuania, Norway, Poland, Russia, Serbia, Slovenia. and Sweden. 